\title{
ASSOCIATION OF AVERAGE TELOMERE LENGTH WITH BODY-MASS INDEX AND VITAMIN D STATUS IN JUVENILE POPULATION WITH TYPE 1 DIABETES POVEZAVA POVPREČNIH DOLŽIN TELOMEROV Z INDEKSOM TELESNE TEŽE IN VITAMINOM D PRI MLADOSTNIKIH S SLADKORNO BOLEZNIJO TIPA 1
}

\author{
Tine TESOVNIK ${ }^{1}$, Jernej KOVAC ${ }^{2}$, Tinka HOVNIK ${ }^{2}$, Primoz KOTNIK ${ }^{1,3}$, Tadej BATTELINO ${ }^{1,3}$, \\ Katarina TREBUSAK PODKRAJSEK ${ }^{2,3, *}$
}

\author{
'University Children's Hospital, Department of Pediatric Endocrinology, Diabetes and Metabolic Diseases, \\ Bohoriceva 20, 1000 Ljubljana, Slovenia \\ 2University Medical Centre Ljubljana, University Children's Hospital, Unit for Special Laboratory Diagnostics, \\ Vrazov trg 1, 1000 Ljubljana, Slovenia \\ ${ }^{3}$ University of Ljubljana, Faculty of Medicine, Vrazov trg 2, 1000 Ljubljana, Slovenia
}

\section{ABSTRACT}

Keywords:

type 1 diabetes, juvenile patients, average telomere length, vitamin $\mathrm{D}$, body mass index

\section{IZVLEČEK}

\section{Ključne besede:}

sladkorna bolezen tipa 1 , otroci, mladostniki, povprečna dolžina telomerov, indeks telesne teže
Background. Type 1 diabetes (T1D) is an autoimmune chronic disease where hyperglycemia, increased risk of oxidative stress, advanced glycation end-products and other genetic and environmental factors lead to T1D complications. Shorter telomeres are associated with hyperglycemic levels and lower serum vitamin D levels.

Methods. Average telomere length (ATL) in whole blood DNA samples was assessed with qPCR method in 53 Slovenian T1D children/adolescents (median age 8.7 years, 1:1.3 male/female ratio). Body mass index standard deviation score (BMI-SDS), glycated haemoglobin and serum level of vitamin D metabolite (25- $(\mathrm{OH})-\mathrm{D} 3)$ and the age at the onset of T1D were collected from the available medical documentation.

Results. Results indicate shorter ATL in subjects with higher BMI-SDS when compared to those with longer ATL $(0.455 \pm 0.438,-0.63 \pm 0.295 ; p=0.049)$. Subjects with higher BMI-SDS had lower serum vitamin $D$ levels when compared to those with lower BMI-SDS (40.66 \pm 3.07 vs. $52.86 \pm 4.85 \mathrm{nmol} / \mathrm{L} ; \mathrm{p}=0.045)$. Vitamin $\mathrm{D}$ serum levels did not significantly differ between subjects with longer/shorter ATL.

Conclusion. T1D children/adolescents with shorter ATL tend to have higher BMI-SDS. Lower serum vitamin D levels were associated with higher BMI-SDS, while associations between vitamin D serum levels, age at the onset of T1D, glycated haemoglobin and ATL were not observed. Additional studies with more participants are required to clarify the role of the telomere dynamics in T1D aetiology and development of complications.

Izhodišče. Sladkorna bolezen tipa 1 (SBT1) je kronična avtoimunska bolezen, pri kateri hiperglikemija ter zvišana raven oksidativnega stresa in končnih produktov glikacije skupaj z genetskimi in okoljskimi dejavniki privedeta do nastanka diabetičnih zapletov. Krajše dolžine telomerov so povezane s hiperglikemičnimi epizodami in nižjimi serumskimi vrednostmi vitamina $D$.

Metode. Z metodo $q P C R$ smo iz vzorcev DNK periferne krvi določili povprečne dolžine telomerov 53 slovenskim bolnikom s SBT1 (povprečna starost 8,7 leta, razmerje med dečki in deklicami 1:1,3). Indeks standardnega odklona indeksa telesne teže (BMI-SDS), vrednosti serumskega metabolita vitamina D 25-hidroksikalcifediola (25-(OH)-D3), glikiran hemoglobin in starost preiskovancev ob izbruhu bolezni smo pridobili iz razpoložljive medicinske dokumentacije.

Rezultati. Rezultati nakazujejo krajše dolžine telomerov pri bolnikih z višjimi vrednostmi BMI-SDS $(0,455 \pm$ $0,438,-0,63 \pm 0,295 ; p=0,049)$. Preiskovanci $z$ višjimi vrednostmi BMI-SDS so imeli nižje vrednosti $25-(O H)-D 3$ kot preiskovanci z nižjimi vrednostmi BMI-SDS $(40,66 \pm 3,07$ proti 52,86 $\pm 4,85 \mathrm{nmol} / \mathrm{L} ; \mathrm{p}=0,045)$. Vrednosti 25-(OH)-D3 niso statistično značilno različne pri preiskovancih z višjimi oziroma nižjimi povprečnimi dolžinami telomerov.

Zaključki. Otroci in mladostniki s SBT1 s krajšimi dolžinami telomerov imajo nekoliko višje vrednosti BMI-SDS. Nižje vrednosti $25-(O H)$-D3 so povezane z višjim BMI-SDS. Povezav med serumskimi vrednostmi 25-(OH)-D3, starostjo bolnikov ob izbruhu bolezni, glikiranim hemoglobinom in povprečnimi dolžinami telomerov nismo zaznali. Za razjasnitev vloge telomerov $v$ etiologiji, patogenezi in nastanku zapletov SBT1 bodo potrebne nadaljnje raziskave $\mathrm{z}$ večjim številom preiskovancev. 


\section{INTRODUCTION}

Telomeres are nucleoprotein structures located at the end of the chromosomes, the role of which is to ensure genomic stability, and prevent chromosomal breaks and fusions. Telomeres are composed of repetitive hexameric DNA sequence TTAGGG, and bounded with proteins of shelterin complex, namely: TRF1, TRF2, TPP1, POT1, RAP1 and TIN2. Their role is the regulation of telomere length, protection, DNA damage repair and control in signalling cascade. At the 3' end of telomere, DNA forms single stranded T loop structure (1) with characteristic secondary quadruplex structures (Figure 1) (2). Telomere length is very variable and can vary between different cell types, chromosomes and even between ends of the same chromosome (3).

Telomere ends are prone to replication shortening due to the inability of the polymerases to completely replicate telomere 3' ends in the process of semiconservative replication (4). The enzyme telomerase reverse transcriptase (TERT) is capable of sustaining telomere stability, but only in steam and germ cells $(5,6)$, while in other somatic cells, TERT expression level is very low and the telomeres are shortened by every cell cycle for 100-200 bases (1), resulting in a limited number of cell replications. When telomeres reach the critical length (Hayflick limit), the cell enters the senescence, stagnation and finally the apoptosis $(4,7)$.

The telomere length is also affected by environmental and genomic factors, transcriptional control, oxidative stress, inflammation, immune system, endocrine system, DNA damage and other. Additionally, mutations in TERT genes can lead to the development of dyskeratosis congenita, aplastic anaemia and other diseases associated with telomere dysregulation $(8,9)$.

Environmental factors, chronic and autoimmune diseases can induce cell stress, resulting in increased cellular concentration of free radicals, which can damage proteins, lipids and nucleic acids (10). Deoxyguanosine has the lowest redox potential of all deoxynucleotides, and is most susceptible to reactions with reactive oxygen species (2). Since telomere tandem repeats are guanosine rich, they present highly susceptible sites for reaction with reactive oxygen species and consequential DNA breaks. Additionally, the shelterin complex attached to the telomeric DNA sequence hampers DNA repair (1). Oxidative stress can also trigger inflammation, which is associated with increased proliferation of immune cells and, consequently, with an increased rate of telomere shortening (9). Inflammation is present in many chronic and autoimmune diseases, such as cardiovascular diseases, rheumatoid arthritis, systemic lupus erythematosus, type 1 and 2 diabetes $(9,11)$. Telomere dynamics and telomere length studies have shown that longer telomere length and slower telomere erosion rate are associated with better health status, better cognitive function, protection from age-related diseases, healthier lipid profile and lower mortality risk (9).

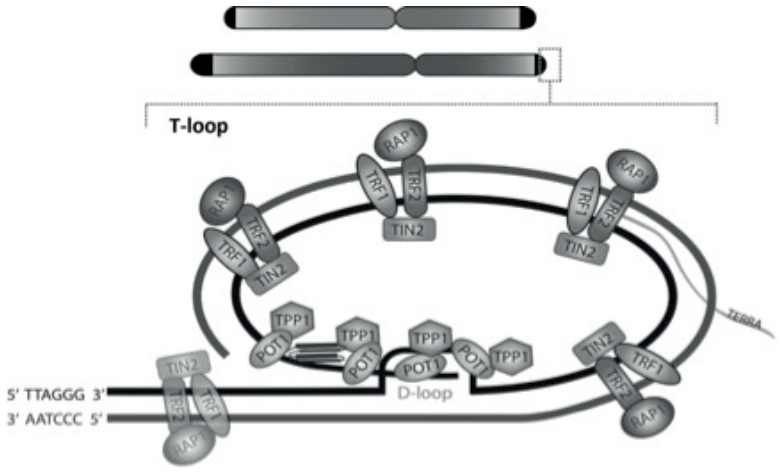

Figure 1. Telomeres and T-loop at the end of telomere. Telomeres are located at the end of chromosomes, their length differs between chromosomes and even between ends of the same chromosome. Proteins of the shelterin complex TRF1, TRF2, RAP1, TIN2, TPP1, POT1 and RNA molecule TERRA are attached to the telomere DNA sequence. The shelterin molecules with telomeric DNA sequence form T-loop, where the 3' end of double-stranded DNA becomes single-stranded, and it is displaced back inside a double-stranded DNA in D-loop area (adopted by reference 1 and 3 ).

\subsection{Telomere Length and Type 1 Diabetes}

Type 1 diabetes (T1D) is a chronic autoimmune disease, characterized by the state of hyperglycemia, as a result of an autoimmune destruction of $B$ pancreatic cells (12). Participants with T1D do not produce enough insulin and require exocrine insulin therapy. Disease develops gradually and bursts innately in childhood (13). Selfcontrol of the blood sugar level and appropriate dosages of insulin are crucial to reduce the risk for development of diabetic complications (14).

Increased levels of reactive oxygen species are present during the development, onset and duration of diabetes $(10,15)$. Only a small number of studies have been published analysing the length of telomeres in T1D. It was reported that T1D subjects have shorter telomere length compared to healthy controls (16); in addition, participants with good glycemic control have longer telomere length than the participants with a poorly-controlled one, but the studies were conducted on a relatively small group of participants (17). The telomere length was also assessed in diabetic participants as a prediction factor for diabetic nephropathy (18) and mortality as a result of diabetic nephropathy (19). Both studies did not show any association between the telomere length and diabetic complications.

Moreover, all published studies have investigated the telomere length in adult population, while the telomere length and telomere dynamics in cohort of juvenile participants with T1D has not been analysed yet. Research on participants with rheumatoid arthritis revealed that participants with an earlier onset of the disease have 
shorter telomere length (20), so we aimed to examine this correlation in T1D as well. The aim was also to characterize telomere length and telomere dynamics in juvenile participants and in addition, to evaluate the potential correlation of telomere length with the available clinical parameters that had been determined at the onset of the disease.

\section{METHODS}

\subsection{Participants}

Fifty-three participants with diagnosed T1D, 23 boys and 30 girls (1:1.3 male/female ratio), were included into the study. The participants were from 4 to 14 years old, with mean age at the onset of the disease $8.65 \pm$ 2.61 years, and no additional diagnosed autoimmune diseases. All participants were diagnosed and treated at The Department of Endocrinology, Diabetes and Metabolic Diseases, University Children's Hospital, UMC Ljubljana, Slovenia.

Available data at the first hospitalization of the participants at the onset of the disease for BMI standard deviation score (BMI-SDS) (mean $0.36 \pm 1.59$ ), age at the onset of the disease (mean $8.65 \pm 2.61$ years), serum metabolite of vitamin D 25-hydroxycalcifediol (25-(OH)-D3) concentration (mean $47.00 \pm 16.66 \mathrm{nmol} / \mathrm{L}$ ) and glycated haemoglobin levels (mean $11.04 \pm 0.26 \%$ ) were collected from the available medical documentation. The research protocol was approved by the Slovene Medical Ethics Committee (Nr: 29/02/13).

\subsection{DNA Isolation}

Genomic DNA was extracted from whole peripheral blood, collected in blood tubes with EDTA, using a FlexiGene DNA isolation kit (Qiagene, Germany) by the established protocol. Extracted DNA was stored on $4{ }^{\circ} \mathrm{C}$ at a concentration of approximately $350 \mathrm{ng} / \mu \mathrm{L}$ for less than 2 years and it was diluted to working DNA stock solution with concentration $5 \mathrm{ng} / \mu \mathrm{L}$.

\subsection{Telomere Length Measurement}

We determined ATL with modified Cawthon's method of monochrome multiplex quantitative real time PCR (MMQPCR) (21). The basic principle of this method is the determination of telomere product $(\mathrm{T})$ and amount of reference gen beta-globin $(S)$ in a single well. Triplicated measurements of $\mathrm{T}$ and $\mathrm{S}$ of the same sample were used to calculate the average $\mathrm{T} / \mathrm{S}$ ratio. The sample used for normalization of the T/S results across different MMQPCR experiments was the DNA sample of the participant with the lowest level of glycated haemoglobin at the onset of the T1D.

PCR reaction mix was composed by $3 \mu \mathrm{L} /$ well MeltDoctor $^{\mathrm{TM}}$ HRM Master Mix (Applied Biosystems $®), 1.00$ pmol/well of each telomere primer (telG: ACACTAAGGTTTGGGTTTGG-
GTTTGGGTTTGGGTTAGTGT; telC: TGTTAGGTATCCCTATC (CTATCCCTATCCCTATCCCTAAC), $0.55 \mathrm{pmol} /$ well of each reference gen beta globin primer (hbgu: CGGCGGCGGGCGGCGCGGGCTGGGCGGcttcatccacgttcaccttg; hbgd: GCCCGGCCCGCCGCGCCCGTCCCGCCGgaggagaagtctgccgt) and $0.02 \mu \mathrm{L} /$ well ROX. Final reaction volume was $6 \mu \mathrm{L} /$ well and it contained $10 \mathrm{ng}$ of sample DNA.

MMQPCR was performed on 96-well plates on Applied Biosystems 7500 Fast Real Time PCR System with twopart program. We determined $\mathrm{Ct}$ value for $\mathrm{T}$ factor of $\mathrm{T} / \mathrm{S}$ analysis in the first run which was immediately followed by the second part of MMQPCR. The Ct value of the second part was used for determination of the amount of the reference gene $(\mathrm{S})$.

The part 1 thermal cycling profile was: $15 \mathrm{~min}$ at $95{ }^{\circ} \mathrm{C}$ (holding stage), 2 cycles of $15 \mathrm{~s}$ at $95^{\circ} \mathrm{C}$ and $15 \mathrm{~s}$ at $95{ }^{\circ} \mathrm{C}$ (cycling stage) and 21 cycles of $15 \mathrm{~s}$ at $95^{\circ} \mathrm{C}, 10 \mathrm{~s}$ at 62 ${ }^{\circ} \mathrm{C}, 15 \mathrm{~s}$ at $71{ }^{\circ} \mathrm{C}$, with signal acquisition (cycling stage), followed by the part 2 thermal profile: 17 cycles of $17 \mathrm{~s}$ at $94{ }^{\circ} \mathrm{C}, 10 \mathrm{~s}$ at $62{ }^{\circ} \mathrm{C}, 15 \mathrm{~s}$ at $74^{\circ} \mathrm{C}, 20 \mathrm{~s}$ at $84{ }^{\circ} \mathrm{C}, 15 \mathrm{~s}$ at $87{ }^{\circ} \mathrm{C}$ with data acquisition (cycling stage), followed holding stage $20 \mathrm{~s}$ on $50{ }^{\circ} \mathrm{C}$. For $\mathrm{Ct}$ determination, the same threshold cycle levels were used in both, part 1 and part 2, runs. The T/S calculation was performed on the samples where the standard deviation of average Ct-value for $\mathrm{T}$ and $\mathrm{S}$ factors across the triplicates did not exceeded $10 \%$.

\subsection{Determination of Telomere Length and Statistical Analysis}

The $\mathrm{Ct}$ data of both experiment runs were used to calculate T/S using $\Delta \Delta \mathrm{Ct}$-method. The average $\mathrm{T} / \mathrm{S}$ of a sample was calculated using data from three parallel experiments, and only results with standard deviation lower than $10 \%$ were included in further analysis. The D'Agostino-Pearson omnibus normality test was performed to assess the data deviation from normal distribution. Consequently, the average T/S values of each sample were correlated against clinical and anthropometric parameters determined at the onset of T1D using Spearman correlation. The differences between upper and lower tertile test groups were assessed with unpaired Welch's t test. The statistical GraphPad Prism software was used for statistical analysis. The p-value below 0.05 was considered to show statistically significant difference or correlation.

\section{RESULTS}

The ATL was assessed in 53 children with T1D and correlated to clinical and anthropometric parameters determined at the time of the disease onset. Average standard deviation of measured T/S values was $5.25 \%$. ATL showed weak negative correlation with BMI-SDS values $(0.241 ; p=0.082)$. This tendency was confirmed with Welch's test of lower and higher ATL tertiles where 
the difference between average BMI-SDS was statistically significant $(0.455 \pm 0.438,-0.630 \pm 0.295 ; \mathrm{p}=0.049)$. The correlation between ATL and other investigated parameters was not present. The analysis also revealed negative correlation between 25-(OH)-D3 and BMI-SDS (0.364; $p=0.018)$, where the participants in lower tertile of BMI-SDS had higher values of $25-(\mathrm{OH})$-D3 than the participants in higher tertile of BMI-SDS (52.86 \pm 4.85 $\mathrm{nmol} / \mathrm{L} ; 40.66 \pm 3.07 \mathrm{nmol} / \mathrm{L} ; \mathrm{p}=0.045)$. The associations between ATL, the participants' age at the time of the T1D onset and the level of glycated haemoglobin were not statistically significant.

\section{DISCUSSION}

This was the first study where ATL of juvenile participants with T1D at the onset of the disease was investigated. The correlation between ATL and the age of the participants at the onset of T1D was not present. The results show a tendency for negative correlation between BMI-SDS and ATL and are in agreement with previously reported large case-control study on French obese children (22). One of the possible explanations for this phenomena is increased chronic inflammation, resulting in higher leukocytes proliferation (23) due to increased oxidative stress in diabetic participants (24). Additionally, it was observed that participants with higher BMI-SDS had lower serum level of vitamin D. Furthermore, the decreased bioavailability of vitamin $D$ from cutaneous and dietary sources in obese people could be caused by increased bioaccumulation in adipose tissue (25). Previous studies have reported that $25-(\mathrm{OH})-\mathrm{D} 3$ has immunomodulatory and preventive role in T1D and that participants with T1D have higher prevalence of $25-(\mathrm{OH})-\mathrm{D} 3$ deficiency (12). Association between serum vitamin D levels and ATL has already been reported, but this association was not observed in our study (26). This may be due to the relatively small number of participants involved in our study. Nevertheless, the telomere length was reported as a biomarker of negative effects of oxidative stress and inflammation and as such, it has a potential as a predictive factor for various disease development (9), especially due to the fact that recent studies revealed an indirect involvement of shelterin complex proteins with the regulation of metabolism (27).

It is crucial to increase the number of participants in future studies to investigate the potential involvement of the telomere dynamics in the aetiology of T1D. Nevertheless, the results confirm the findings of the previously reported studies, and indicate that the modified MMQPCR method is adequate for ATL assessment. It would also be reasonable to introduce age matching healthy controls to identify the potential additional correlations between ATL and other parameters, and to elucidate if the factors of telomere dynamics have a role in the development of T1D.

\section{CONCLUSION}

T1D children/adolescents with a shorter ATL tend to have a higher BMI-SDS. Additionally, lower serum vitamin D levels were determined in T1D subjects with a higher BMISDS, while associations between serum vitamin D levels, glycated haemoglobin and ATL were not determined. Additional research with a higher number of participants would be required to clearly establish the role of the telomere dynamics in T1D aetiology.

\section{CONFLICTS OF INTEREST}

The authors declare that no conflicts of interest exist.

\section{FUNDING}

This work was partly supported by the Slovenian Research Agency grants J3-6800, J3-6798 and P3-0343.

\section{ETHICAL APPROVAL}

The research protocol was approved by the Slovene Medical Ethics Committee (Nr: 29/02/13).

\section{REFERENCES}

1. O'Sullivan RJ, Karlseder J. Telomeres: protecting chromosomes against genome instability. Nat Rev Mol Cell Biol 2010; 11: 171-81.

2. Fleming $A M$, Burrows CJ. G-quadruplex folds of the human telomere sequence alter the site reactivity and reaction pathway of Guanine oxidation compared to duplex DNA. Chem Res Toxicol 2013; 26: 593-607.

3. O'Callaghan NJ, Fenech M. A quantitative PCR method for measuring absolute telomere length. Biol Proced Online 2011; 13: 3.

4. Von Zglinicki T. Oxidative stress shortens telomeres. Trends Biochem Sci 2002; 27: 339-44.

5. Gomez DE, Armando RG, Farina HG, Menna PL, Cerrudo CS, Ghiringhelli PD. et al. Telomere structure and telomerase in health and disease: review. Int J Oncol 2012; 41: 1561-9.

6. Xi H, Li C, Ren F, Zhang H, Zhang L. Telomere, aging and age-related diseases. Aging Clin Exp Res 2013; 25: 139-46.

7. Hohensinner PJ, Goronzy JJ, Weyand CM. Telomere dysfunction, autoimmunity and aging. Aging Dis 2011; 2: 524-37.

8. Weng N. Telomeres and immune competency. Curr Opin Immunol 2012; 24: 470-5.

9. Shalev I. Early life stress and telomere length: investigating the connection and possible mechanisms: a critical survey of the evidence base, research methodology and basic biology. BioEssays News Rev Mol Cell Dev Biol 2012; 34: 943-52.

10. Rains JL, Jain SK. Oxidative stress, insulin signaling, and diabetes. Free Radic Biol Med 2011; 50: 567-75.

11. Georgin-Lavialle S, Aouba A, Mouthon L, Londono-Vallejo JA, Lepelletier Y, Gabet AS. et al. The telomere/telomerase system in autoimmune and systemic immune-mediated diseases. Autoimmun Rev 2010; 9: 646-51.

12. Chakhtoura M, Azar ST. The role of vitamin d deficiency in the incidence, progression, and complications of Type 1 diabetes mellitus. Int J Endocrinol 2013: 148673. Epub 2013 Mar 13. 
13. Drobnič Radobuljac M, Bratina N, Tomori M, Battelino T. Type 1 diabetes and psychosocial risk factors in adolescence. Zdrav Vest 2012; 81: 664-75.

14. American Diabetes Association. Diagnosis and classification of diabetes mellitus. Diabetes Care 2012; 36(Suppl 1): S67-74.

15. Hovnik T, Dolzan V, Bratina NU, Podkrajsek KT, Battelino T. Genetic polymorphisms in genes encoding antioxidant enzymes are associated with diabetic retinopathy in type 1 diabetes. Diabetes Care 2009; 32: 2258-62.

16. Jeanclos E, Krolewski A, Skurnick J, Kimura M, Aviv H, Warram JH. et al. Shortened telomere length in white blood cells of patients with IDDM. Diabetes 1998; 47: 482-6.

17. Uziel O, Singer JA, Danicek V, Sahar G, Berkov E, Luchansky M. et al. Telomere dynamics in arteries and mononuclear cells of diabetic patients: effect of diabetes and of glycemic control. Exp Gerontol 2007; 42: 971-8.

18. Fyhrquist F, Tiitu A, Saijonmaa O, Forsblom C, Groop P-H, FinnDiane Study Group. Telomere length and progression of diabetic nephropathy in patients with type 1 diabetes. J Intern Med 2010; 267: 278-86.

19. Astrup AS, Tarnow L, Jorsal A, Lajer M, Nzietchueng R, Benetos A. et al. Telomere length predicts all-cause mortality in patients with type 1 diabetes. Diabetologia 2010; 53: 45-8.

20. Colmegna I, Diaz-Borjon A, Fujii H, Schaefer L, Goronzy JJ, Weyand CM. Defective proliferative capacity and accelerated telomeric loss of hematopoietic progenitor cells in rheumatoid arthritis. Arthritis Rheum 2008; 58: 990-1000.
21. Cawthon RM. Telomere length measurement by a novel monochrome multiplex quantitative PCR method. Nucleic Acids Res 2009; 37: e21-21.

22. Buxton JL, Walters RG, Visvikis-Siest S, Meyre D, Froguel P, Blakemore AIF. Childhood obesity is associated with shorter leukocyte telomere length. J Clin Endocrinol Metab 2011; 96: 1500-5.

23. Aviv A, Valdes AM, Spector TD. Human telomere biology: pitfalls of moving from the laboratory to epidemiology. Int J Epidemiol 2006; 35: 1424-9.

24. Domínguez C, Ruiz E, Gussinye M, Carrascosa A. Oxidative stress at onset and in early stages of type 1 diabetes in children and adolescents. Diabetes Care 1998; 21: 1736-42.

25. Wortsman J, Matsuoka LY, Chen TC, Lu Z, Holick MF. Decreased bioavailability of vitamin D in obesity. Am J Clin Nutr 2000; 72: 690-3.

26. Liu JJ, Prescott J, Giovannucci E, Hankinson SE, Rosner B, Han J. et al. Plasma vitamin D biomarkers and leukocyte telomere length. Am J Epidemiol 2013; 177: 1411-7.

27. Martínez P, Gómez-López G, García F, Mercken E, Mitchell S, Flores JM. et al. RAP1 protects from obesity through its extratelomeric role regulating gene expression. Cell Rep 2013; 3: 2059-74. 